\title{
Phosphorus Leaching from an Organic and a Mineral Arable Soil in a Rainfall Simulation Study
}

\author{
Matthew Riddle, ${ }^{*}$ Lars Bergström, Frank Schmieder, Holger Kirchmann, Leo Condron, and Helena Aronsson
}

\begin{abstract}
Phosphorus derived from agricultural systems has been found to cause eutrophication of surface waters. To combat this, the specific location of soil profile $P$ release is necessary for development of effective mitigation strategies. This paper describes a $P$ leaching study of two Swedish arable soils, an organic (Typic Haplosaprist) and a mineral soil (Typic Hapludalf), both with high $\mathrm{P}$ content. Undisturbed soil columns isolated 0 - to 20-, 20- to 40-, 40- to 60-, and 60- to 80-cm depth intervals. These were placed in a rainfall simulator and subjected to four $50-\mathrm{mm}$ rainfall events to identify the origin of $\mathrm{P}$ leachate as a function of soil depth interval and physicochemical properties. Phosphorus losses were greatest from the two uppermost layers of both soils after $200 \mathrm{~mm}$ of artificial rainfall was applied at $5 \mathrm{~mm} \mathrm{~h}^{-1}$. Total $\mathrm{P}$ concentration in leachate from the 0 - to $20-\mathrm{cm}$ layer ranged from 2.1 to $8.8 \mathrm{mg} \mathrm{L}^{-1}$ for the mineral and 3.7 to $10.3 \mathrm{mg} \mathrm{L}^{-1}$ from the organic soil, with most (95-100\%) in dissolved reactive $P$ form. Degree of $P$ saturation correlated well with total $P$ leaching losses from the organic soil $(R=0.84)$ but not the mineral soil $(R=0.69)$, suggesting that the presence of $\mathrm{Al}$ and Fe (hydr) oxides has a stronger influence on P leaching in the organic soil. Results indicate that both soils have the potential to contribute concentrations of $\mathrm{P}$ above those known to cause eutrophication of surface waters.
\end{abstract}

\section{Core Ideas}

- The majority of P leached from both soils was from the top $20 \mathrm{~cm}$, in DRP form.

- Phosphorus concentrations in leachate were higher from the organic than the mineral soil.

- Degree of P saturation correlated well with P leached from the organic soil.

- High rainfall application promoted losses of P potentially complexed to DOC and Fe or Al.

- Both soils leached concentrations of $\mathrm{P}$ above those known to cause eutrophication.

Copyright $\odot$ American Society of Agronomy, Crop Science Society of America, and Soil Science Society of America. 5585 Guilford Rd., Madison, WI 53711 USA.

All rights reserved.

\section{J. Environ. Qual. 47:487-495 (2018)}

doi:10.2134/jeq2018.01.0037

This is an open access article distributed under the terms of the CC BY-NC-ND

license (http://creativecommons.org/licenses/by-nc-nd/4.0/).

Supplemental material is available online for this article.

Received 23 Jan. 2018.

Accepted 4 Apr. 2018.

*Corresponding author (matthew.riddle@slu.se).
$\mathrm{P}$ HOSPHORUS LOSSES from mineral agricultural soils have been studied intensively (Addiscott et al., 2000; Godlinski et al., 2004; Liu et al., 2012), producing a variation of $\mathrm{P}$ loads and concentrations from both field and lysimeter studies. Variability in P losses can be explained by soil characteristics, including fertilization history (Heckrath et al., 1995), soil texture (Djodjic et al., 1999), flow pathways (Jarvis, 2007), and the presence of sorption sites (Cui and Weng, 2013; Simmonds et al., 2015). Surface runoff is generally recognized as the main pathway for P transport from these soils (Daniel et al., 1994); however, subsurface pathways can also play an important role (Maguire and Sims, 2002). This is also a common way of P transport within organic soils due to low bulk density and intensive field drainage (Daniel et al., 1994; Simmonds et al., 2017).

Arable organic soils account for $\sim 10$ million ha or $<1 \%$ of the world's 3270 million ha of potential arable land (Blume et al., 2015) and have received considerably less attention for P losses. In Sweden, $7 \%$, or $\sim 225,000$ ha of arable soils are classified as organic soils (Berglund and Berglund, 2008; Lundblad, 2015). Only one organic soil was included in an agricultural monitoring program in Sweden that has been following drainage flows and $\mathrm{P}$ concentrations from 16 fields since the early 1970s (Ulén et al., 2001). Phosphorus leaching concentrations and loads from that organic soil were among the highest of those monitored, with a mean annual concentration of $0.15 \mathrm{mg} \mathrm{P} \mathrm{L}^{-1}$ and an annual load of $0.49 \mathrm{~kg} \mathrm{P} \mathrm{ha}^{-1}$ over a 19 -yr period. One recent $\mathrm{P}$ leaching experiment involving a Swedish organic soil was conducted by Parvage et al. (2015). They measured mean concentrations of $3.4 \mathrm{mg} \mathrm{P} \mathrm{L} \mathrm{L}^{-1}$ and loads of $8 \mathrm{~kg} \mathrm{P} \mathrm{ha}^{-1}$ in leachate after applying $300 \mathrm{~mm}(\sim 50 \%$ of annual rainfall) in a rain simulation study using organic topsoil columns $(0-20 \mathrm{~cm})$. These two examples suggest that organic soils could be particularly vulnerable to large $P$ leaching losses.

The mobilization and transport mechanism of $\mathrm{P}$ in soils results from the physicochemical processes of sorption-desorption and precipitation-dissolution (Bünemann et al., 2012). The

M. Riddle, L. Bergström, and H. Aronsson, Water Quality Management Group, Dep. Soil and Environment, Swedish Univ. of Agricultural Sciences, PO Box 7014, SE75007 Uppsala, Sweden; F. Schmieder and H. Kirchmann, Plant Nutrition and Soil Fertility Group, Dep. Soil and Environment, Swedish Univ. of Agricultural Sciences, PO Box 7014, SE-75007 Uppsala, Sweden; L. Condron, Faculty of Agriculture and Life Sciences, PO Box 84, Lincoln Univ., Lincoln 7647, Canterbury, New Zealand. Assigned to Associate Editor Anthony Buda.

Abbreviations: $\mathrm{Al}_{\mathrm{ox}^{\prime}}$ oxalate-extractable aluminum; $\mathrm{DOC}$, dissolved organic carbon; DPS, degree of phosphorus saturation; DRP, dissolved reactive phosphorus; $\mathrm{Fe}_{\text {ox }^{\prime}}$ oxalate-extractable iron; ICP-OES, inductively coupled plasma spectrometry; P-AL, ammonium lactate-extractable phosphorus; $\mathrm{P}_{\text {ox' }}$ oxalate-extractable phosphorus; PP, particulate phosphorus; PVC, polyvinyl chloride; SMHI, Swedish Meteorological and Hydrological Institute. 
presence or absence of $\mathrm{Al}, \mathrm{Fe}$ (hydr)oxides, Ca, clay minerals, and organic matter (Cui and Weng, 2013; Fink et al., 2016; Gérard, 2016; Bulmer et al., 2018) are all important when evaluating potential P losses in soil. Organic matter is known to compete with $\mathrm{P}$ for sorption sites; however, previous studies have found it unlikely to bind directly with P (McDowell and Condron, 2001). This is also the case in organic-rich soils with noncrystalline or organically bound $\mathrm{Al}$ and $\mathrm{Fe}$ versus soils with low organic matter content (Kang et al., 2009). Instead, it has been suggested that the formation of metal-organic matter complexes can provide sites for $\mathrm{P}$ sorption (McDowell and Condron, 2001).

Identification of soils prone to $P$ leaching has been performed by calculating the saturation of potential P binding sites in a soil, known as the degree of $\mathrm{P}$ saturation (DPS). van der Zee and van Riemsdijk, (1988) used oxalate-extractable $\mathrm{Fe}\left(\mathrm{Fe}_{\text {ox }}\right), \mathrm{Al}\left(\mathrm{Al}_{\text {ox }}\right)$, and $\mathrm{P}\left(\mathrm{P}_{\mathrm{ox}}\right)$ in acid sandy soils to identify the proportion of binding sites occupied by $\mathrm{P}$, which indicates potential soil $\mathrm{P}$ desorbability (Beauchemin et al., 1998). In short, the higher the DPS, the greater the potential for P losses. Since the development of this method, there have been other variations using Mehlich-1 or Mehlich-3 extractable P, Fe, and Al (Nair et al., 2004) for calculating a saturation index or combinations of both oxalate and Mehlich methods (Nair and Graetz, 2002). Degree of P saturation has also been found to be an effective option for organic soils (Litaor et al., 2003), which have typically low concentrations of P-binding Al and Fe oxides (Miller, 1979; Simmonds et al., 2015), in comparison with mineral soils. Low concentrations of these P-binding oxides have also been found to be related to higher $\mathrm{P}$ leaching losses from organic soils in a prior study (Cogger and Duxbury, 1984).

Phosphorus release in the soil profile is generally accepted to be from the P-rich topsoil, and therefore investigations into $\mathrm{P}$ release from topsoil, mineral or organic, have traditionally involved 20-cm-long column studies (Liu et al., 2012; Svanbäck et al., 2013; Parvage et al., 2015). However, by removing the subsoil, potential P sorption or desorption sites are neglected, and therefore actual total P losses are unrealistic. Full-length lysimeters (Haygarth and Jarvis, 1997; Leinweber et al., 1999) can determine P losses from the whole soil profile, but specific questions related to individual soil layer contributions are not answerable. Full-length lysimeters with and without topsoil (Andersson et al., 2015) have also been used to determine whether the subsoil is a sink or a source of P. Clearly, determination of which technique to use is dependent on the specific research study aim.

The first objective of this study was to identify the source of $\mathrm{P}$ leaching losses in an arable organic soil profile and identify the mechanism causing these losses. The second objective was to quantify and compare these organic soil P losses to the $\mathrm{P}$ losses from an intensively farmed mineral soil with a history of high P leaching. To meet these objectives, a rainfall simulation experiment was performed with undisturbed soil columns from two soils and four $20-\mathrm{cm}$ layers, to a depth of $80 \mathrm{~cm}$. High rainfall application rates were used to identify the worst-case P leaching concentrations and loads from these soils and their individual layers. This study firstly provided valuable knowledge for improved strategic placement of future mitigation strategies, aimed at reducing P leaching; second, it provided important $\mathrm{P}$ adsorption-desorption data obtained from the same soils to compare with data from a future whole-profile lysimeter study.

\section{Materials and Methods}

\section{Soils}

The organic soil was chosen, on the basis of depth to underlying clay $(>75 \mathrm{~cm})$ and a history of intensive arable use, from a site located in south-central Sweden near the city of Örebro $\left(59^{\circ} 11^{\prime} 30.91^{\prime \prime} \mathrm{N}, 15^{\circ} 35^{\prime} 7.83^{\prime \prime} \mathrm{E}\right)$. It was classified as a Typic Haplosaprist according to the USDA Natural Resource Conservation Service classification system. The sampling site was reclaimed swampland that had been tile drained in the early 1940s. The organic layer thickness predominately exceeded $75 \mathrm{~cm}$, with gyttja clay underneath. Gyttja indicates a fine grain organic matter in sediment, formed in lake or seabed and has a characteristic light gray color with poor water infiltration when water saturated. Calcium within the profile was determined not to be calcareous due to almost identical total $\mathrm{C}$ and organic $\mathrm{C}$ contents. Drainage pipes were present at a depth of 80 to $100 \mathrm{~cm}$. Crops such as wheat (Triticum aestivum L.) and carrots [Daucus carota subsp. sativus (Hoffm.) Arcang.] have been grown annually, with mineral $\mathrm{P}$ fertilizer applied at a rate of $\sim 18 \mathrm{~kg} \mathrm{Pha}^{-1} \mathrm{yr}^{-1}$.

A loamy, sand-textured, Ca-rich soil (mineral soil) classified as a Typic Hapludalf was collected from a farm outside Kristianstad in southern Sweden $\left(56^{\circ} 3^{\prime} 38.64^{\prime \prime} \mathrm{N}\right.$, $14^{\circ} 3^{\prime} 0.79^{\prime \prime} \mathrm{E}$ ), $\sim 500 \mathrm{~km}$ south of Örebro. Large inputs ( $45 \mathrm{t}$ $\mathrm{ha}^{-1} \mathrm{yr}^{-1}$ ) of cow slurry (on average $31 \mathrm{~kg} \mathrm{P} \mathrm{ha}^{-1} \mathrm{yr}^{-1}$ ) were applied over the past $40 \mathrm{yr}$, resulting in a nutrient-rich topsoil. The sand soil was tile drained to assist in water removal due to a percolating water table and a drainage-impeding clay layer present at around the 2-m depth. Mean annual unfiltered total $\mathrm{P}$ losses in drainage water of $1.5 \mathrm{~kg} \mathrm{ha}^{-1} \mathrm{yr}^{-1}(1979-2010)$ have been recorded, with maximum values of $2.8 \mathrm{~kg} \mathrm{ha}^{-1} \mathrm{yr}^{-1}$ (Data Hosting Agricultural Land, 2016). This is considerably higher than the average total P leaching losses of $0.4 \mathrm{~kg} \mathrm{ha}^{-1} \mathrm{yr}^{-1}$ from arable land in Sweden (Bergström et al., 2007).

Soil samples for chemical and physical analysis were collected at $20-\mathrm{cm}$ intervals (i.e., at $0-20,20-40,40-60$ and $60-80 \mathrm{~cm}$ ) from the organic soil. Intervals of $10 \mathrm{~cm}$ were instead used for the mineral soil, as this was part of another study. These 10-cm depths were then averaged to $20-\mathrm{cm}$ intervals to enable comparisons with the organic soil (i.e., $0-10+10-20 \mathrm{~cm}$ ). Results were averaged together, giving one $20-\mathrm{cm}$ result. After collection, all soil samples were placed in a refrigerator at $3^{\circ} \mathrm{C}$ and were then air dried, milled, and sieved $(<2.0 \mathrm{~mm})$ before analysis. Detailed physical and chemical data from both soils are presented in Table 1 .

\section{Soil Column Excavation}

In November 2014, a tractor-mounted rear hydraulic press with a $1.5-\mathrm{m}$-long vertical hydraulic ram was used to extract undisturbed $20-\mathrm{cm}$ soil columns. These columns were collected at depths of 0 to 20, 20 to 40,40 to 60 , and 60 to $80 \mathrm{~cm}$ at each of the two sites. A $25-\mathrm{cm}$-high polyvinyl chloride (PVC) sewer pipe with $20-\mathrm{cm}$ external diameter $(18.8-\mathrm{cm}$ i.d.) was placed at the desired soil depth. The hydraulic ram was lowered onto the PVC pipe and pressed down $20 \mathrm{~cm}$ at a constant speed. Three replicates were taken from each layer at both sites. Columns were excavated by hand, capped, and kept in darkness at $\sim 5^{\circ} \mathrm{C}$ until March 2015, when rain simulations began. 
Table 1. Selected soil physical and chemical properties of the organic and mineral soils.

\begin{tabular}{|c|c|c|c|c|c|c|c|c|c|c|}
\hline Soil & Depth & $\mathrm{pH}+$ & Total C & Bulk density & $\mathrm{C} / \mathrm{N}$ & Total Ca & Total Al & Total Fe & $\mathrm{Al}_{\mathrm{ox}} \neq$ & $\mathrm{Fe}_{\mathrm{ox}} \neq$ \\
\hline & $\mathrm{cm}$ & & $\%$ & $\mathrm{~g} \mathrm{~cm}^{3}$ & & \multicolumn{3}{|c|}{$\mathrm{mg} \mathrm{kg}^{-1}$} & \multicolumn{2}{|c|}{$-\mathrm{mmol} \mathrm{kg}{ }^{-1}-$} \\
\hline \multirow[t]{4}{*}{ Organic } & $0-20$ & 5.1 & 42.9 & 0.3 & 14.1 & $21,144.8$ & $3,737.7$ & $4,732.0$ & 68.7 & 65.1 \\
\hline & $20-40$ & 5.1 & 30.8 & 0.2 & 13.1 & $16,206.6$ & $10,992.1$ & $9,157.5$ & 72.6 & 48.5 \\
\hline & $40-60$ & 5.8 & 30.3 & 0.2 & 22.8 & $19,126.5$ & $23,891.7$ & $7,420.4$ & 120.2 & 115.5 \\
\hline & $60-80$ & 5.5 & 36.5 & 0.4 & 22.5 & $21,737.2$ & $10,001.4$ & $11,742.7$ & 98 & $102.4 \S$ \\
\hline \multirow[t]{4}{*}{ Mineral } & $0-20$ & 7.3 & 2.0 & 1.29 & 10.1 & $4,982.6$ & $4,957.0$ & $5,963.9$ & 39.9 & 32.0 \\
\hline & $20-40$ & 7.5 & 1.0 & 1.29 & 8.7 & $3,776.4$ & $3,729.1$ & $4,839.0$ & 23.8 & 22.0 \\
\hline & $40-60$ & 7.7 & 0.2 & 1.29 & 8.2 & $2,150.4$ & $2,695.2$ & $8,212.6$ & 9.9 & 38.8 \\
\hline & $60-80$ & 7.9 & 0.1 & 1.39 & 10.3 & $2,055.9$ & $2,429.7$ & $4,321.4$ & 5.3 & 9.5 \\
\hline
\end{tabular}

† Extracted in water.

$\neq \mathrm{Al}_{\text {ox }}$ and $\mathrm{Fe}_{\mathrm{ox}}$, oxalate-extractable $\mathrm{Al}$ and $\mathrm{Fe}$, respectively.

$\S$ Result for the 60 - to $70-\mathrm{cm}$ layer only.

ๆ Data from another unpublished source.

\section{Rain Simulator}

The rainfall simulator described by Liu et al. (2012) was used to measure potential $P$ leaching from the layers within the two soils. It was also used to identify the origin of $\mathrm{P}$ in the profile under a worst-case scenario involving heavy rain, repeated every few days. The simulator is a stainless steel cabinet fitted with 10 sprayer nozzles, $40 \mathrm{~cm}$ apart and $60 \mathrm{~cm}$ above the soil surface (Supplemental Fig. S1). Artificial rainwater was prepared according to precipitation analyzed by the Swedish Meteorological and Hydrological Institute (SMHI) in the Örebro and Stockholm regions. On exiting the simulator, the rainwater contained $278 \mu \mathrm{g} \mathrm{Ca} \mathrm{L}{ }^{-1}, 6.85 \mu \mathrm{g} \mathrm{Fe} \mathrm{L}^{-1},<400 \mu \mathrm{g} \mathrm{K} \mathrm{L}^{-1},<90 \mu \mathrm{g} \mathrm{Mg} \mathrm{L}^{-1}$, $352 \mu \mathrm{g} \mathrm{Na} \mathrm{L}{ }^{-1}$, and $<1 \mu \mathrm{g}$ total $\mathrm{P} \mathrm{L}^{-1}$, had $\mathrm{pH} 5.8$, and had an electrical conductivity of $0.008 \mathrm{mS} \mathrm{m}^{-1}\left(0.1047 \mathrm{mmol} \mathrm{L}^{-1}\right)$.

The columns were prepared by drawing a $50-\mu \mathrm{m}$ polyamide filter cloth under the base and then placed on top of a stainless steel mesh (pore size $=0.5 \mathrm{~mm}$ ) in a shallow, stainless steel container to allow leachate to pass freely from the base. A polyethylene tube was connected from a nipple at the container outlet to a glass bottle underneath the simulator, which allowed direct flow of leachate to the bottles. A PVC sleeve was slipped over the outside of the PVC column and stainless steel container and sealed at the top with duct tape to prevent unwanted rainwater bypassing the column and entering the container (Supplemental Fig. S1). Each simulation involved a random rearrangement of the columns in the simulator. After each simulation ended, $2 \mathrm{~d}$ were allowed for drainage to cease and the leachate was then weighed.

\section{Leaching Experiment}

To allow the soils time to equilibrate to the $22^{\circ} \mathrm{C}$ indoor temperature, the columns were removed from the refrigerator and left outside the rainfall simulation room for $1 \mathrm{wk}$ prior to starting the simulations. First, they were placed in 10-L buckets and saturated from the bottom upward with the artificial rainwater solution for $2 \mathrm{~d}$, to enable columns to saturate similarly before the experiment began. Columns were allowed to drain for a further $2 \mathrm{~d}$, at which time they were deemed to be at field capacity.

A rainfall application rate of $5 \mathrm{~mm} \mathrm{~h}^{-1}$ was set by an onoff sequence of 11 to $29 \mathrm{~s}$, cycling every $2 \mathrm{~min}$ (adjustable for each nozzle) by a logger program. Pretests indicated a range of 4.5 to $5.5 \mathrm{~mm} \mathrm{~h}^{-1}$ (10\% variation), which was deemed acceptable. Each simulation ran for $10 \mathrm{~h}(50 \mathrm{~mm})$. The total amount of rainfall applied to each soil column during the four simulation events was $200 \mathrm{~mm}(\sim 5.6 \mathrm{~L})$, and the total time the columns were in the rain simulator or draining was 12 to $14 \mathrm{~d}$ including 2 to $3 \mathrm{~d}$ between simulation events. Even though the artificial rainfall rate for this period of time is high, Wern (2012) wrote in a SMHI report on high precipitation events in Sweden (1900-2011) that 60\% of the highest precipitation events recorded occurred in the study site region, where a 1-in-100-yr rainfall event (annual exceedance probability of $1 \%$ ) could produce 164 to $185 \mathrm{~mm}$ precipitation in a $24-\mathrm{h}$ period (equivalent to 68-77 $\mathrm{mm}$ over $10 \mathrm{~h}$ ).

\section{Soil and Leachate Analysis}

Soil

Because the soil $\mathrm{pH}$ ranged between 5.1 and 5.5 in the organic soil samples and between 7.3 and 7.9 in the mineral soil samples, soil $\mathrm{P}$ concentrations were extracted using both ammonium lactate-extractable P (P-AL) and Olsen P (Table 2). The P-AL method with an extraction $\mathrm{pH}$ of 3.75 suited the organic soil, whereas Olsen-P with pH 8.5, used for extracting Ca-P, was suited to the high-pH mineral soil. First, soil samples were extracted using ammonium lactate $(0.1 \mathrm{M})$ and acetic acid $(0.4 \mathrm{M})$ at $\mathrm{pH} 3.75$ and a soil/solution ratio of 1:20 (P-AL method; Egnér et al., 1960). Extracts were analyzed for $\mathrm{P}$ using inductively coupled plasma spectrometry (ICP-OES; Optima 7300 DV, PerkinElmer). Olsen P was analyzed according to the standard method (Olsen and Sommers, 1982), whereby soil was extracted in $0.5 \mathrm{M}$ sodium bicarbonate at $\mathrm{pH} 8.5$ and measured using Flow Injection Analysis (FIAstar 5000, AN 5246, FOSS). Total P, Fe, Al, and Ca were extracted with concentrated $\mathrm{HNO}_{3}$ on a hotplate and digested in three stages: first at $60^{\circ} \mathrm{C}$ for $2 \mathrm{~h}$, then $100^{\circ} \mathrm{C}$ for $1 \mathrm{~h}$, and finally $130^{\circ} \mathrm{C}$ for $2 \mathrm{~h}$. Analysis was performed using ICP-OES as above. Total $\mathrm{C}$ was determined by the dry combustion method (LECO, 2014 ) at $1350^{\circ} \mathrm{C}$ using a LECO Tru-Mac CNS 2000 analyzer.

Oxalate-extractable $\mathrm{Fe}, \mathrm{Al}$, and $\mathrm{P}$ were extracted using a standard method (ÖNORM L1 1201, Austrian Standard) whereby soil samples were ground and mixed at a soil/solution ratio of 1:100 and then extracted with $0.2 \mathrm{M}$ ammonium oxalate-oxalic acid by shaking for $4 \mathrm{~h}$ in darkness according to Schwertmann (1964). These extracts were also analyzed using ICP-OES. The $\mathrm{pH}$ was determined using dry soil samples mixed with distilled water at a ratio $(\mathrm{w} / \mathrm{v})$ of $1: 5$. 
Table 2. Different soil P analyses from the organic and mineral soils.

\begin{tabular}{|c|c|c|c|c|c|c|}
\hline Soil & Depth & Total P & Olsen P† & P-AL\# & $P_{o x} \S$ & DPSף \\
\hline & $\mathrm{cm}$ & 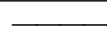 & $-\mathrm{mg} \mathrm{kg}^{-1}$ & 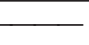 & $\mathrm{mmol} \mathrm{kg}{ }^{-1}$ & $\%$ \\
\hline \multirow[t]{4}{*}{ Organic } & $0-20$ & 1285.4 & 61 & 152.3 & 18.6 & 27.9 \\
\hline & $20-40$ & 1199.8 & 110 & 279.1 & 12.7 & 21.2 \\
\hline & $40-60$ & 498.4 & 5.8 & 17.5 & 8.8 & 7.5 \\
\hline & $60-80$ & 587.8 & 25 & 75.6 & $7.5 \#$ & 7.5 \\
\hline \multirow[t]{4}{*}{ Mineral } & $0-20$ & 1194 & 120 & 609.1 & 33.2 & 92.1 \\
\hline & $20-40$ & 881.5 & 80 & 439.4 & 21.1 & 77.3 \\
\hline & $40-60$ & 530.4 & 12.5 & 200.8 & 6.5 & 26.6 \\
\hline & $60-80$ & 472.7 & 8.1 & 248.4 & 3.1 & 49.3 \\
\hline
\end{tabular}

† Sodium bicarbonate-extractable P.

‡ P-AL, extractable in ammonium acetate lactate solution.

$\S \mathrm{P}_{\mathrm{ox}}$, oxalate-extractable $\mathrm{P}$.

ๆ DPS, degree of phosphorus, calculated as $\mathrm{P}_{\mathrm{ox}} /\left[0.5\left(\mathrm{Fe}_{\mathrm{ox}}+\mathrm{Al}_{\mathrm{ox}}\right)\right] \times 100$, where $\mathrm{Fe}_{\mathrm{ox}}$ and $\mathrm{Al}_{\mathrm{ox}}$ are oxalate-extractable $\mathrm{Fe}$ and $\mathrm{Al}$, respectively.

\# Result for the 60- to 70-cm layer only.

The DPS (\%) was calculated as

$\mathrm{DPS}=\mathrm{P}_{\mathrm{ox}} / \alpha\left(\mathrm{Al}_{\mathrm{ox}}+\mathrm{Fe}_{\mathrm{ox}}\right) \times 100$

where DPS is the degree of $\mathrm{P}$ saturation (\%), $\mathrm{P}_{\text {ox }}, \mathrm{Al}_{\text {ox }}$, and $\mathrm{Fe}_{\text {ox }}$ are the oxalate-extractable $\mathrm{P}, \mathrm{Al}$, and $\mathrm{Fe}$, respectively $\left(\mathrm{mmol} \mathrm{kg}^{-1}\right)$, and $\alpha$ is the empirical factor used to compare soils with respect to their P saturation (Nair et al., 2004; Schoumans and Chardon, 2015). An $\alpha$ value between 0.5 and 0.6 was first suggested by van der Zee and van Riemsdijk (1988), and 0.5 has also been used by others (Breeuwsma and Silva, 1992; Schoumans, 2013; Schoumans and Chardon, 2015). Freese et al. (1995) reported an effective maximum P sorption capacity of $\alpha=0.48$ from 17 German agricultural soils, suggesting that 0.5 is an appropriate value in this study.

\section{Leachate}

Leachate was weighed $2 \mathrm{~d}$ after cessation of each simulation event, and a subsample of $250 \mathrm{~mL}$ was delivered to the laboratory directly after each event and preserved in accordance with their standard procedures.

All samples were analyzed for total $\mathrm{P}$, total dissolved $\mathrm{P}$, and dissolved reactive $\mathrm{P}$ (DRP) according to the ammonium molybdate method (European Committee for Standardization, 1996). In short, phosphate reacts with molybdate and antimony potassium tartrate in an acid environment. The complex formed is converted into a compound with a blue color by reduction with ascorbic acid. The absorbance at $880 \mathrm{~nm}$ gives a measure of the orthophosphate content. Total $\mathrm{P}$ was analyzed on unfiltered samples and total dissolved $\mathrm{P}$ on filtered samples (0.2- $\mu \mathrm{m}$ pore size, Schleicher \& Schüll). The smaller filter size was to capture fine clay particles common in Swedish drainage water (Ulén, 2004). Both samples were acidified with sulfuric acid (4 M) and digested with potassium peroxodisulfate (5\%) at $120^{\circ} \mathrm{C}$ for $30 \mathrm{~min}$, following the Bran \& Luebbe Method no. G-175-96 Revision 2 (modified), and analyzed using a Technicon Autoanalyzer 3. The DRP content was analyzed on undigested filtered samples using colorimetry (Gallery Plus, Thermo Fisher Scientific). The difference between total $\mathrm{P}$ and total dissolved $\mathrm{P}$ was defined as particulate $\mathrm{P}(\mathrm{PP})$, whereas the remainder (i.e., total P - DRP-PP) was classified as dissolved unreactive $\mathrm{P}$ or residual $\mathrm{P}$. The residual $\mathrm{P}$ fraction was assumed to be a close estimate for organic P. Leachate from two replicate samples from each soil was analyzed further for $\mathrm{Fe}$, $\mathrm{Al}, \mathrm{Ca}$, and dissolved organic C (DOC). Aluminum and $\mathrm{Fe}$ were analyzed according to the ISO 1185:2009 method. This involved addition of $1.4 \mathrm{~g} \mathrm{HNO}_{3} \mathrm{~mL}^{-1}$ and heating to complete digestion, removal of excess water by evaporation, addition of water and $\mathrm{HCl}\left(1.16 \mathrm{~g} \mathrm{~mL}^{-1}\right)$, and warming for $15 \mathrm{~min}$. Analysis was performed using inductively coupled plasma atomic emission spectroscopy (PerkinElmer OPTIMA 2100). Calcium was analyzed on conserved samples without digestion using inductively coupled mass spectrometry (Agilent 7900). Dissolved organic $C$ samples were filtered through a $0.45-\mu \mathrm{m}$ filter and then acidified with $\mathrm{HCl}$. The $\mathrm{CO}_{2}$ was removed by flushing samples with synthetic $\mathrm{O}_{2}$ just before injection into a Shimadzu TOC-VCPH analyzer, during which samples were combusted at $720^{\circ} \mathrm{C}$ and the $\mathrm{CO}_{2}$ produced was read using an infrared detector. Electrical conductivity was measured using a CDM210 conductivity meter connected to a TIM900 Titration Manager (Radiometer Analytical) and processed using TimTalk software (Labsoft, 2007)

\section{Statistical and Data Analysis}

Soil columns were completely randomized before each rain simulation. All statistical analyses were performed using R Studio (R Core Team, 2014). The two soils were analyzed separately using a general linear mixed model with depth and simulation as fixed factors, which included assessment of their interactions. To account for the split-plot structure with all four simulations used on each of the replicates at each depth, a random factor indicating the hierarchical factor "replicate" was included. Since residuals in the model for total P concentrations were not normally distributed, log-transformed total $P$ was used as the response variable. Pairwise comparisons were made between each simulation for the same soil and depth for multiple comparisons using a least squares mean method that incorporates Tukey's adjustment, allowing for more conservative analysis. Differences between simulations were considered significant at $P<0.05$. Geometric means and their respective geometric SD are presented here. Nutrient loads $\left(\mathrm{kg} \mathrm{ha}^{-1}\right)$ were calculated by multiplying geometric mean concentration ( $\mathrm{mg}$ $\mathrm{L}^{-1}$ ) analyzed in leachate samples by amount of discharge (L) and scaling to 1 ha. 


\section{Results and Discussion}

\section{Soil Properties}

The P-AL values exceeded the Olsen P values for both soils, suggesting dissolution of more $\mathrm{P}$ bound to $\mathrm{Fe}$ and $\mathrm{Al}$ oxides and also to $\mathrm{Ca}$, due to the lower $\mathrm{pH} \mathrm{P}$-AL extraction compared with the higher $\mathrm{pH}$ Olsen P extraction (Eriksson et al., 2013). Bulk density was significantly lower in the organic soil (Table 1), which was attributed to the high total $\mathrm{C}$ content. To enable comparisons between the soils, a range of analytical values are presented in both milligrams per kilogram in Tables 1 and 2, and in milligrams per cubic centimeter in Supplemental Table S2.

The total P concentrations in the full soil profile were similar for both soils (Table 2). However, when accounting for bulk density, the mineral soil contained nearly four times more total $\mathrm{P}$ per unit volume. The soil total $\mathrm{P}$ content in the organic soil decreased from the 0 - to $20-\mathrm{cm}$ layer to the $60-$ to $80-\mathrm{cm}$ layer, as did the percentage of P-AL in total P (from 8 to $1 \%$ ). The total $\mathrm{P}$ values in the mineral soil were highest in the two uppermost layers, where $95 \%$ of Olsen $\mathrm{P}$ was found. A higher $\mathrm{P}-\mathrm{AL}$ $\left(279 \mathrm{mg} \mathrm{P} \mathrm{kg}{ }^{-1}\right)$ and Olsen $\mathrm{P}\left(110 \mathrm{mg} \mathrm{P} \mathrm{kg}^{-1}\right)$ were recorded at the 20- to $40-\mathrm{cm}$ layer in the organic soil, exceeding those in the layer directly above. However, this was contrary to $\mathrm{P}_{\text {ox }}$ and total $\mathrm{P}$, which both indicated a decrease in $\mathrm{P}$ with soil depth. This could suggest that $P_{\text {ox }}$ had extracted more $P$ from the 0 - to $20-\mathrm{cm}$ layer than the AL-P and Olsen P methods, as the $\mathrm{P}_{\text {ox }}$ method derives from selective dissolution of soil Fe forms to extract Fe-P (Wuenscher et al., 2016). Moreover, the 0- to 20-cm layer has a $\mathrm{Fe}_{\text {ox }}$ of 65.1 compared with $48.5 \mathrm{mmol} \mathrm{kg}^{-1}$ from the 20 - to 40-cm layer (Table 1), which could indicate that there is more Fe-P in the top layer that was not extracted by P-AL or Olsen P, but instead by $\mathrm{P}_{\text {ox }}$ and total $\mathrm{P}$ methods.

\section{Discharge Volumes}

The target rainfall amount applied to each column during each 10-h simulation was $50 \mathrm{~mm}$. Discharge ranged between 33 and $62 \mathrm{~mm}(50$ [mean] \pm 6.34 [SD]) for the organic and 31 and $61 \mathrm{~mm}(49 \pm 7.1)$ for the mineral soil. Leachate amounts were statistically analyzed between each simulation for each soil and layer individually, and no significant differences were found.

\section{Phosphorus Leaching Losses as a Function of Soil Test Phosphorus and Depth}

Intensive inputs of fertilizers can enrich the topsoil of any soil (Liu et al., 2012). Thus, Haygarth and Jarvis (1999) suggested that fertilizer history and application time, and climate conditions, can affect $\mathrm{P}$ leaching. The considerable amounts of fertilizer and manure applied to the surface of the two experimental soils over the past 30 to $70 \mathrm{yr}$ has resulted in higher concentrations of $\mathrm{P}$ in the surface layers (Table 2). This was also reflected in elevated $\mathrm{P}$ leaching losses from the top $40 \mathrm{~cm}$ of both soils (Fig. 1A, 1B, 1E, and 1F). Most (85\%) of the P loads came from the uppermost $(0-$ to $20-\mathrm{cm})$ layer in the organic soil, which gave a total $\mathrm{P}$ concentration in leachate of between 3.7 and $10.3 \mathrm{mg}$ $\mathrm{L}^{-1}$ from all simulations. Almost all leached P (98-100\%) was in DRP form, with lower concentrations of residual P and PP. The total P loads from this same layer produced $1.9 \mathrm{~kg} \mathrm{ha}^{-1}$ in Rain Simulation 1 and up to $4.7 \mathrm{~kg} \mathrm{ha}^{-1}$ from the fourth simulation.
A previous rainfall simulation study by Parvage et al. (2015), on an organic soil with similar soil total $P$ values to this study, found lower mean total $\mathrm{P}$ concentrations in leachate from the 0 - to 20-cm layer $\left(3.4 \mathrm{mg} \mathrm{L}^{-1}\right)$ than observed in this study $(7.7 \mathrm{mg}$ $\left.\mathrm{L}^{-1}\right)$. However, the DPS value in their 0 - to 20 -cm layer was $15 \%$ compared with $28 \%$ for the 0 - to 20 -cm layer of the organic soil in the present study, which could explain the difference. They found that DRP accounted for $\sim 75 \%$ of total $\mathrm{P}$ in their leachate. Similarly, Reddy (1983) found that 70 to $89 \%$ of total P in leachate from a southern Florida peat soil was in orthophosphate (DRP) form.

The 20- to 40-cm layer of the organic soil had lower total P concentrations and loads than the 0 -to 20 -cm layer, with concentrations ranging between 0.36 (Rain Simulation 3) and $2.52 \mathrm{mg}$ $\mathrm{L}^{-1}$ (Rain Simulation 2), and loads between 0.50 and $0.62 \mathrm{~kg}$ $\mathrm{ha}^{-1}$. The 40- to 60- and 60- to $80-\mathrm{cm}$ layers produced little total $\mathrm{P}$ leaching in the organic soil (Table 3). Particulate $\mathrm{P}$ and residual $\mathrm{P}$ losses increased at lower depths, in some cases up to $30 \%$ in either form. However, the concentrations and calculated total loads from these layers were relatively small.

The mineral soil had similar results, with the majority of $\mathrm{P}$ leaching loads $(60 \%)$ originating from the top $40 \mathrm{~cm}$. In these top two layers, $100(0-20 \mathrm{~cm})$ and $98 \%(20-40 \mathrm{~cm})$ of $P$ in leachate, was in the DRP form from all four rainfall simulations. In a previous laboratory study, Riddle and Bergström (2013) found the majority of P lost from 20-cm sand columns was also in DRP form. Parvage et al. (2015) compared a loamy sand and a loam soil $(0-20 \mathrm{~cm})$ in a rain simulator study and found mean total $\mathrm{P}$ concentrations in leachate of 0.02 and $0.62 \mathrm{mg} \mathrm{L}^{-1}$, respectively. These values are lower than the concentrations found in the mineral soil in this current study (average total P in leachate of $7.7 \mathrm{mg} \mathrm{L}^{-1}$ ), likely due to the high soil test $\mathrm{P}$ values (Olsen P, $\mathrm{P}_{\mathrm{ox}}$, and $\left.\mathrm{P}-\mathrm{AL}\right)$ in the mineral soil. In contrast with the organic soil, the $40-$ to $60-\mathrm{cm}$ and 60 - to $80-\mathrm{cm}$ layers of the mineral soil leached $40 \%$ of the mean whole profile total P load as PP (Fig. $1 \mathrm{G}$ and $1 \mathrm{H}$ ), and an explanation is provided in the section below.

An associated disadvantage of a $20-\mathrm{cm}$ soil column study is the segmentation effect on the P dynamics in the soil leaching process. As each soil column's leachate was individually collected, potential resorption in lower layers of $\mathrm{P}$ released from upper layers is completely negated, and for this reason, no total profile $\mathrm{P}$ losses have been suggested. This is, however, the shortcoming when targeting specific questions relating to the identification and quantification of $\mathrm{P}$ in the soil profile.

\section{Effect of Rainwater lonic Strength on Phosphorus Losses}

The application of $200 \mathrm{~mm}$ of low ionic strength synthetic rainwater over a 2 -wk period reduced the electrical conductivity in the leachate from 1000 to $383 \mu \mathrm{s} \mathrm{cm}^{-1}$ in the organic soil and 1050 to $341 \mu \mathrm{s} \mathrm{cm}^{-1}$ from the mineral soil 0 - to 20 -cm layers. A large decrease of $\mathrm{Ca}^{2+}$ in leachate from the 0 - to 20-cm layer of both soils from Simulations 1 to 4 (Supplemental Table S1) also occurred, potentially as the soil attempted to maintain chemical equilibrium in the soil-water interface. $\mathrm{As}^{\mathrm{Ca}^{2+}}$ is one of the predominant exchangeable cations in agricultural soils (Lindsay and Moreno, 1960), it was likely initially released into solution during the first simulation, but by the fourth simulation, the easily mobilized $\mathrm{Ca}^{2+}$ pool was potentially depleted. Also affected by the rainwater ionic strength in this layer was 

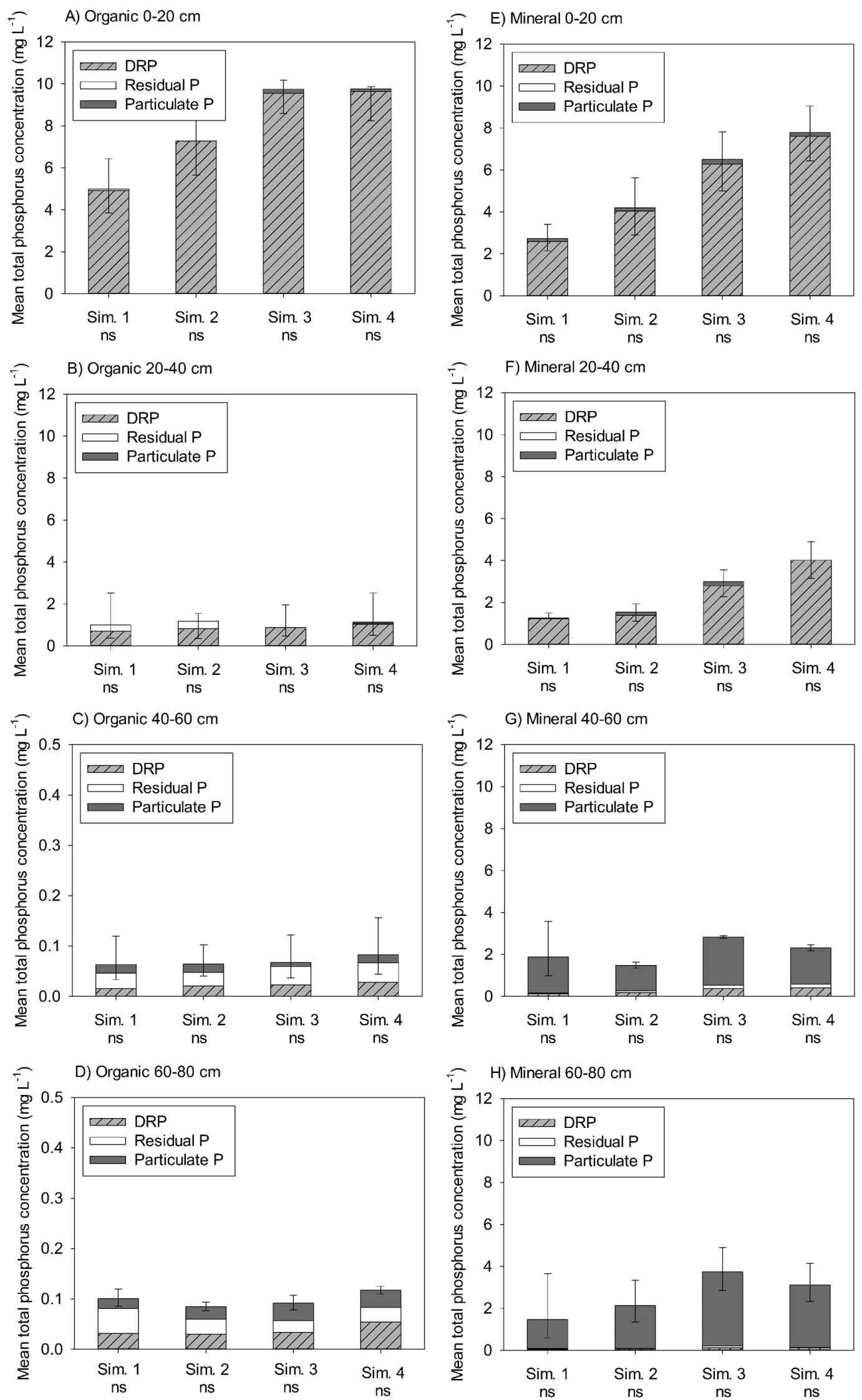

Fig. 1. Geometric mean total $\mathrm{P}$ concentration in leachate collected from $20-\mathrm{cm}$ soil columns from two soils after four rainfall simulation (Sim.) events: in organic soil (A) 0- to 20-, (B) 20- to 40-, (C) 40- to 60-, and (D) 60- to 80-cm layers; in mineral soil (E) 0- to 20-, (F) 20- to 40-, (G) 40- to 60-, and $(\mathrm{H}) 60$ - to $80-\mathrm{cm}$ layers. Simulations with different letters underneath have significantly different values $(P<0.05)$ for total $P$ concentrations ("ns" indicates no significant difference). Error bars represent geometric SD, which is multiplicative and therefore cannot be added or subtracted from the geometric mean. Upper and lower SD thresholds are calculated by geometric mean $\times$ geometric SD and geometric mean/geometric SD, respectively. DRP, dissolved reactive P. Note the different $y$-axis scales. 
Table 3. Combined mean total $P$ leaching loads from the different layers of the two soils after four rainfall simulation events. Values are based on geometric means multiplied by discharge volume. $\dagger$

\begin{tabular}{lccc}
\hline Soil & Depth & $\begin{array}{c}\text { Sum of mean } \\
\text { leaching loads }\end{array}$ & Geometric SD \\
\hline \multirow{3}{*}{ Organic } & $\mathrm{cm}$ & 15.0 & kg total P ha ${ }^{-1}-1$ \\
& $0-20$ & 1.8 & 2.2 \\
& $20-40$ & 0.2 & 1.8 \\
& $40-60$ & 0.2 & 1.1 \\
Mineral & $60-80$ & 9.6 & 1.2 \\
& $0-20$ & 4.6 & 1.3 \\
& $20-40$ & 4.7 & 1.1 \\
& $40-60$ & 5.0 & 1.3 \\
\hline
\end{tabular}

†These results are after $200 \mathrm{~mm}$ of artificial rainfall (about one-third of annual rainfall) was applied.

the DOC concentration in leachate (Supplemental Table S1). This increased from Rain Simulations 1 to 4, resulting in a negative correlation between $\mathrm{Ca}^{2+}$ and DOC in two of the mineral soil $(R=-0.85$ and -0.96$)$ and two of the organic soil $(R=-0.98$ and -0.98$)$ replicates that were analyzed for $\mathrm{Ca}^{2+}$ and DOC. A review paper by Kalbitz et al. (2000) stated that DOC mobilization is negatively linked to the ionic strength of rainwater, which has also been confirmed in field monitoring of streams in the Czech Republic (Hruška et al., 2009). A strong positive correlation between $\mathrm{DOC}$ and $\mathrm{Fe}$ and $\mathrm{Al}$ from both soils (Supplemental Table S1) was also found in the current study. Moreover, a statistically nonsignificant $(P>0.05)$ increase in total $\mathrm{P}$ and DRP concentration occurred in leachate during the four rain simulations from both soils at the 0 - to 20-cm layer (Fig. 1A and $1 \mathrm{E}$ ) and for the mineral soil at the 20- to 40-cm layer (Fig. 1F). A potential complex of DOC, Fe, $\mathrm{Al}$, and DRP has been explained by Gerke (2010), who found that DRP is not bound directly to humic matter, but instead to metals (e.g., $\mathrm{Al}^{3+}$ and $\mathrm{Fe}^{3}$ ) complexed by humic substances, mainly carboxylic and phenolic groups (de Wit et al., 1993). This implies that heavy rainfall events could also promote $\mathrm{P}$ loss from the 0- to 20-cm layer. However, the impact of this on $\mathrm{P}$ reaching surface waters will be dependent on the $\mathrm{P}$ sorption capacity of the lower soil layers.

The clay and fine silt $(<0.002 \mathrm{~mm})$ content in the mineral $(1-3 \%)$ and organic $(22-33 \%)$ soil (range for layers $40-80 \mathrm{~cm}$ ) may provide insight into why PP was dominant in leachate from the mineral soil 40 - to 60- and 60- to 80-cm layers and, to a lesser extent, in the same layers of the organic soil (Fig. 1C, 1D, 1E, and $1 \mathrm{H})$. These soil layers are naturally fed ion-rich water from the soil layers above; however, in this study, they received low-ionicstrength rainwater $(0.1047 \mathrm{mmol} \mathrm{L})$, which likely resulted in an experimental artifact. Low-ionic-strength solutions have been found to cause an expansion of the diffuse double layer between soil colloids and grains. This results in an increase in repulsive interactions and, finally, promotes colloid detachment (Kallay, 1987). This phenomenon has been found to increase with high flow rates (Ryan and Gschwend, 1994). Humus potentially increased the cohesion and stability of the clay colloids in the organic soil (Tisdall and Oades, 1982) as compared with the mineral soil, resulting in lower PP losses. Moreover, $\mathrm{P}$ content in the 40- to 60- and 60- to 80-cm layers (Supplemental Table S2) are much higher in the mineral than the organic soil, and thus $\mathrm{P}$ bound to the detached colloids could explain the proportionally different amounts of PP measured in leachate.

\section{Degree of Phosphorus Saturation}

The highest leached $\mathrm{P}$ concentrations and loads came from the top $40 \mathrm{~cm}$ of both soils, which was also the layer with the highest concentrations of P-AL and Olsen P. Plant-available P (P-AL or Olsen P) can be an indicator of leachable P. However, regression models between $\mathrm{P}-\mathrm{AL}$ or Olsen $\mathrm{P}$ at different depths with total $P$ concentrations in leachate from the organic soil were not statistically significant. The corresponding analysis for the mineral soil gave no correlation for P-AL, but a better correlation for Olsen $\mathrm{P}(R=0.75)$. Djodjic et al. (2004) found no relationship between extractable soil $\mathrm{P}$ (Olsen $\mathrm{P}$ and $\mathrm{P}-\mathrm{AL})$ and $\mathrm{P}$ leaching in mineral soils, pointing out instead the importance of subsoil properties and water transport mechanisms on P losses. Börling et al. (2004) concluded that P-AL or Olsen P analysis is not sufficient alone to predict $\mathrm{P}$ losses, and that $\mathrm{P}$ sorption properties are also important. Kuntze and Scheffer (1979) found that close to $100 \%$ of triple superphosphate added to their sphagnum moss peat soil columns was leached out due to the absence of $\mathrm{Fe}$ and $\mathrm{Al}$ oxides and hydroxides.

The DPS is a function of the occupied portion of the soils' exchangeable sites that are bound with $\mathrm{P}$, in relation to the number of sites available for $\mathrm{P}$ binding capacity, which ultimately indicates the potential desorbability of soil-bound $\mathrm{P}$ (Zhang et al., 2005). The P equilibrium concentration in solution has been found to increase with higher DPS (Sibbesen and Sharpley, 1997; Andersson et al., 2015), which can lead to greater P leaching. Critical DPS values of 30 (Smet et al., 1995; Leinweber et al., 1997), 25 (Breeuwsma and Silva, 1992), and $5 \%$ (5th and 95th percentile values of 1 and 36) (Schoumans and Chardon, 2015) have been suggested for different soil textures, with the last specifically for peat soils in the Netherlands. Soil DPS threshold values above these critical values can increase the risk of surface water deterioration. As organic soil properties are variable and there are limited DPS values proposed for organic soils in literature, a median value of $25 \%$ was chosen to satisfy both soil textures in this study and the range of values in literature. The DPS method was originally based on noncalcareous sandy soils where $\mathrm{P}$ was bound to metal oxides (van der Zee and van Riemsdijk, 1988). When used for soils with high $\mathrm{pH}$ and Ca-rich minerals but no carbonate content, as in this study, the acid $\mathrm{P}_{\text {ox }}$ extraction method can overestimate available $\mathrm{P}$ by dissolving Ca-bound P (Peltovuori et al., 2002; Koopmans et al., 2007). Concurrent research performed on the same soils as in this study identified a potential maximum of $30 \%$ Ca-bound P in the top $40 \mathrm{~cm}$ of the mineral soil using X-ray absorption near edge structure (XANES) spectroscopy (Schmieder et al., 2018). This suggests that overestimation of available $P$ in the top $40 \mathrm{~cm}$ by $\mathrm{P}_{\text {ox }}$ extraction is likely. The 0 - to $20-\mathrm{cm}$ layer from the organic soil was the only layer over the $25 \%$ limit (DPS $=27.9 \%)$. This contrasts Litaor et al. (2003), who reported DPS values of 0.8 to $16.4 \%$ for 10 Histosols in Israel. Moreover, seven peat soils included in a European study returned a mean DPS value of $12.1 \pm 4$ (Meissner et al., 2008). This suggests that the current study DPS values are relatively high, likely due to the history of fertilizer P inputs. Interestingly, the 20- to 40-cm layer DPS was calculated at $21.2 \%$, which is slightly less than the $0-$ to $20-\mathrm{cm}$ 
layer DPS of 27.9\% (Table 2). However, the leaching load from the 0 - to 20-cm layer was eightfold more than in the 20 - to $40-\mathrm{cm}$ layer. This could suggest an underestimation of the $\mathrm{P}$ sorption capacity in this 20- to 40-cm layer. Comparison of $\mathrm{Al}$ and $\mathrm{Fe}$ with total $\mathrm{Al}$ and total $\mathrm{Fe}$ in the 20- to 40-cm layer (Table 1) reveals that nearly threefold and twofold more $\mathrm{Al}$ and $\mathrm{Fe}$, respectively, are extracted using the total extraction method. This could be interpreted as the oxalate extraction method potentially underestimating available $\mathrm{Al}$ and or $\mathrm{Fe}$ in this soil. Alternatively, the $25 \%$ DPS threshold value could be seen as a tipping point above which $\mathrm{P}$ desorption rapidly increases.

In the mineral soil, all DPS values were $>25 \%$, and the highest value of $92 \%$ was calculated for the 0 - to $20-\mathrm{cm}$ layer. Although the absolute DPS values in the mineral soil were likely overestimated due to the $\mathrm{P}_{\text {ox }}$ extraction method, the DPS values in Table 2 match the high leaching loads in Table $3(R=0.84$ for the organic soil, $R=0.69$ for the mineral soil). Previous DPS studies on alkaline calcareous soils using Olsen P and Mehlich-3 $\mathrm{Ca}$ and $\mathrm{Mg}$ extraction have proved successful (Ige et al., 2005); however, using this method on acid organic soils would likely cause an underestimation of extracted $\mathrm{P}$, which highlights the issue of comparing soils with a large $\mathrm{pH}$ difference.

As there were only four data points for each DPS versus leached $P$ load regression, conclusions drawn should be conservative; however, DPS can give a better measure of P desorption and leaching than soil $\mathrm{P}$ concentration, especially in the organic soil.

\section{Conclusions}

This study provided valuable data about potential P leachate contributions from different soil layers of an organic soil compared with a mineral soil. Concentrations of $\mathrm{P}$ in leachate from both soils were well above suggested threshold values contributing to eutrophication of surface waters, with leachate from the organic soil having $>1000$ times the suggested eutrophication threshold value of $0.01 \mathrm{mg} \mathrm{P} \mathrm{L}{ }^{-1}$. Losses of $\mathrm{P}$ were correlated with DPS in different soil layers, suggesting that $\mathrm{Al}$ and $\mathrm{Fe}$ (hydr)oxides affect $\mathrm{P}$ losses from both mineral and organic soil. The upper $20 \mathrm{~cm}$ of soil contributed the most to total P losses, and almost all losses were as DRP from both soils, indicating that $\mathrm{P}$ in these two soils behaves similarly and that $\mathrm{P}$ mitigation measures targeting DRP lost from the topsoil are necessary. A complementary full-length lysimeter study under field conditions is now suggested to investigate the complex $\mathrm{P}$ desorption and resorption interactions of the individual soil layers together and, in doing so, give a better estimate of whole profile P losses.

\section{Supplemental Material}

Available online are color images of the rainfall simulation equipment, a table including leachate analysis from specific soil columns, and also a table of selected soil chemical analysis converted into weight per volume units.

\section{Acknowledgments}

We wish to thank The Swedish Research Council for Environment, Agricultural Sciences and Spatial Planning (Formas) for financial support, the late Göran Johansson for help with extracting the soil columns, and the respective farmers for the use of their land and facilities. Thank you also to Claudia von Brömssen for her statistics expertise and Mary McAfee for her linguistic proficiency.

\section{References}

Addiscott, T.M., D. Brockie, J.A. Catt, D.G. Christian, G.L. Harris, K.R. Howse, et al. 2000. Phosphate losses through field drains in a heavy cultivated soil. J. Environ. Qual. 29:522-532. doi:10.2134/jeq2000.00472425002900020021x

Andersson, H., L. Bergström, B. Ulén, F. Djodjic, and H. Kirchmann. 2015. The role of subsoil as a source or sink for phosphorus leaching. J. Environ. Qual. 44:535544. doi:10.2134/jeq2014.04.0186

Beauchemin, S., R.R. Simard, and D. Cluis. 1998. Forms and concentration of phosphorus in drainage water of twenty-seven tile-drained soils. J. Environ. Qual. 27:721-728. doi:10.2134/jeq1998.00472425002700030033x

Berglund, Ö., and K. Berglund. 2008. Farmed organic soils in Sweden 2003. Tech. Rep. 7. (In Swedish, with English abstract.) Swedish Univ. of Agric. Sci., Uppsala.

Bergström, L., F. Djodjic, H. Kirchmann, I. Nilsson, and B. Ulén. 2007. Phosphorus from farmland to water-status, flows and preventative measures in a Nordic perspective. Food Rep. 21. no. 4/2007. Swedish Univ. of Agric. Sci., Uppsala.

Blume, H.-P., G.W. Brümmer, H. Fleige, R. Horn, E. Kandeler, I. Kögel-Knabner, et al. 2015. Scheffer/Schachtschabel soil science. Springer-Verlag, Berlin, Heidelberg.

Börling, K., E. Otabbong, and E. Barberis. 2004. Soil variables for predicting potential phosphorus release in Swedish noncalcareous soils. J. Environ. Qual. 33:99106. doi: 10.2134 /jeq2004.9900

Breeuwsma, A., and S. Silva. 1992. Phosphorus fertilisation and environmental effects in the Netherlands and the Po region (Italy). Agric. Res. Dep., The Winand Staring Ctr. Integr. Land, Soil, Water Res., Wageningen, the Netherlands.

Bulmer, D., G. Kar, J. Hamilton, S. Siciliano, and D. Peak. 2018. Extent and mechanism of interaction between phosphate and citrate in a calcareous soil. Soil Sci. Soc. Am. J. 82:315-322. doi:10.2136/sssaj2017.08.0289

Bünemann, E.K., A. Oberson, F. Liebisch, F. Keller, K.E. Annaheim, O. HugueninElie, and E. Frossard. 2012. Rapid microbial phosphorus immobilization dominates gross phosphorus fluxes in a grassland soil with low inorganic phosphorus availability. Soil Biol. Biochem. 51:84-95. doi:10.1016/j.soilbio.2012.04.012

Cogger, C., and J.M. Duxbury. 1984. Factors affecting phosphorus losses from cultivated organic soils. J. Environ. Qual. 13:111-114. doi:10.2134/ jeq1984.00472425001300010020x

Cui, Y., and L. Weng. 2013. Arsenate and phosphate adsorption in relation to oxides composition in soils: LCD modeling. Environ. Sci. Technol. 47:7269-7276. doi:10.1021/es400526q

Daniel, T.C., A.N. Sharpley, D.R. Edwards, R. Wedepohl, and J.L. Lemunyon. 1994. Minimizing surface water eutrophication from agriculture by phosphorus management. J. Soil Water Conserv. http://agris.fao.org/agris-search/search. do? recordID=US9509868 (accessed 3 Jan. 2016).

Data Hosting Agricultural Land. 2016. Databas SLU Jordbruksvatten version 2017:2. (In Swedish). Swedish Univ. of Agric. Sci., Uppsala. www.slu.se/jordbruksvatten (accessed 11 June 2017)

de Wit, J.C., W.H. van Riemsdijk, and L.K. Koopal. 1993. Proton binding to humic substances. 2. Chemical heterogeneity and adsorption models. Environ. Sci. Technol. 27:2015-2022. doi:10.1021/es00047a005

Djodjic, F., L. Bergström, B. Ulén, and A. Shirmohammadi. 1999. Mode of transport of surface-applied phosphorus-33 through a clay and sandy soil. J. Environ. Qual. 28:1273-1282. doi:10.2134/jeq1999.00472425002800040031x

Djodjic, F., K. Börling, and L. Bergström. 2004. Phosphorus leaching in relation to soil type and soil phosphorus content. J. Environ. Qual. 33:678-684. doi:10.2134/ jeq2004.6780

Egnér, H., H. Riehm, and W. Domingo. 1960. Untersuchungen über die chemische bodenanalyse als grundlage für die beurteiling des nährstoffzustandes der böden: II. Chemische extraktionsmethoden zur phosphor und kaliumbestimmung. (In German.) Kungliga Lantbrukshögskolans Annaler 26: 199-215.

Eriksson, A.K., B. Ulén, L. Berzina, A. Iital, V. Janssons, A.S. Sileika, and A. Toomsoo. 2013. Phosphorus in agricultural soils around the Baltic Sea: Comparison of laboratory methods as indices for phosphorus leaching to waters. Soil Use Manage. 29:5-14. doi:10.1111/j.1475-2743.2012.00402.x

European Committee for Standardization. 1996. Water quality: Determination of phosphorus: Ammonium molybdate spectrometric method. Eur. Stand. EN 1189. Eur. Comm. Stand., Brussels.

Fink, J.R., A.V. Inda, T. Tiecher, and V. Barrón. 2016. Iron oxides and organic matter on soil phosphorus availability. Cienc. Agrotecnol. 40:369-379. doi:10.1590/1413-70542016404023016

Freese, D., W.H. van Riemsdijk, and S.E.A.T.M. van der Zee. 1995. Modelling phosphate-sorption kinetics in acid soils. Eur. J. Soil Sci. 46:239-245. doi:10.1111/j.1365-2389.1995.tb01832.x

Gérard, F. 2016. Clay minerals, iron/aluminium oxides, and their contribution to phosphate sorption in soils: A myth revisited. Geoderma 262:213-226. doi:10.1016/j.geoderma.2015.08.036

Gerke, J. 2010. Humic (organic matter)-Al(Fe)-phosphate complexes: An underestimated phosphate form in soils and source of plant-available phosphate. Soil Sci. 175:417-425. doi:10.1097/SS.0b013e3181f1b4dd

Godlinski, F., P. Leinweber, R. Meissner, and J. Seeger. 2004. Phosphorus status of soil and leaching losses: Results from operating and dismantled lysimeters after 15 experimental years. Nutr. Cycl. Agroecosyst. 68:47-57. doi:10.1023/ B:FRES.0000012235.80656.cd 
Haygarth, P.M., and S.C. Jarvis. 1997. Soil derived phosphorus in surface runoff from grazed grassland lysimeters. Water Res. 31:140-148. doi:10.1016/ S0043-1354(99)80002-5

Haygarth, P.M., and S.C. Jarvis. 1999. Transfer of phosphorus from agricultural soil. Adv. Agron. 66:195-249. doi:10.1016/S0065-2113(08)60428-9

Heckrath, G., P.C. Brookes, P.R. Poulton, and K.W.T. Goulding. 1995. Phosphorus leaching from soils containing different phosphorus concentrations in the Broadbalk experiment. J. Environ. Qual. 24:904-910. doi:10.2134/ jeq1995.00472425002400050018x

Hruška, J., P. Krám, W.H. McDowell, and F. Oulehle. 2009. Increased dissolved organic carbon (DOC) in Central European streams is driven by reductions in ionic strength rather than climate change or decreasing acidity. Environ. Sci. Technol. 43:4320-4326. doi:10.1021/es803645w

Ige, D.V., O.O. Akinremi, and D.N. Flaten. 2005. Environmental index for estimating the risk of phosphorus loss in calcareous soils of Manitoba. J. Environ. Qual. 34:1944-1951. doi:10.2134/jeq2004.0468

Jarvis, N.J. 2007. A review of non-equilibrium water flow and solute transport in soil macropores: Principles, controlling factors and consequences for water quality. Eur. J. Soil Sci. 58:523-546. doi:10.1111/j.1365-2389.2007.00915.x

Kalbitz, K., S. Solinger, J.H. Park, B. Michalzik, and E. Matzner. 2000. Controls on the dynamics of dissolved organic matter in soils: A review. Soil Sci. 165:277-304. doi:10.1097/00010694-200004000-00001

Kallay, N. 1987. Diffusional detachment of colloidal particles from solid/solution interfaces. Adv. Colloid Interface Sci. 27:1-42. doi:10.1016/0001-8686(87)85008-X

Kang, J., D. Hesterberg, and D.L. Osmond. 2009. Soil organic matter effects on phosphorus sorption: A path analysis. Soil Sci. Soc. Am. J. 73:360-366. doi:10.2136/sssaj2008.0113

Koopmans, G.F., W.J. Chardon, and R.W. McDowell. 2007. Phosphorus movement and speciation in a sandy soil profile after long-term animal manure applications. J. Environ. Qual. 36:305-315. doi:10.2134/jeq2006.0131

Kuntze, H., and B. Scheffer. 1979. Phosphate mobility in relation to fertilizing effects in raised-bog peat. (In German, with English abstract.) Z. Pflanzenernahrung Bodenkd. 142:155-168. doi:10.1002/jpln.19791420205

Labsoft. 2007. TimTalk 9. Version 2.1. Labsoft, Virum, Denmark.

LECO. 2014. Carbon/nitrogen in soil and plant tissue. LECO. http://www.lecochina.cn/home/index/downfile/dir/CNPSTruMac/name/8TRUMAC_CARBON_NITROGEN_SOIL_PLANT_TISSUE_203-821-437 (accessed 20 Sept. 2017).

Leinweber, P., F. Lünsmann, and K.U. Eckhardt. 1997. Phosphorus sorption capacities and saturation of soils in two regions with different livestock densities in northwest Germany. Soil Use Manage. 13:82-89. doi:10.1111/j.1475-2743.1997. tb00562.x

Leinweber, P., R. Meissner, K.-U. Eckhardt, and J. Seeger. 1999. Management effects on forms of phosphorus in soil and leaching losses. Eur. J. Soil Sci. 50:413-424 10.1046/j.1365-2389.1999.00249.x

Lindsay, W.L., and E.C. Moreno. 1960. Phosphate phase equilibria in soils. Soil Sci. Soc. Am. J. 24:177-182. doi:10.2136/sssaj1960.03615995002400030016x

Litaor, M.I., O. Reichmann, M. Belzer, K. Auerswald, A. Nishri, and M. Shenker. 2003. Spatial analysis of phosphorus sorption capacity in a semiarid altered wetland. J. Environ. Qual. 32:335-343. doi:10.2134/jeq2003.3350

Liu, J., H. Aronsson, B. Ulén, and L. Bergström. 2012. Potential phosphorus leaching from sandy topsoils with different fertilizer histories before and after application of pig slurry: Phosphorus leaching from sandy topsoils. Soil Use Manage. 28:457467. doi:10.1111/j.1475-2743.2012.00442.x

Lundblad, M. 2015. Land use on organic soils in Sweden. SMED Rep. 199. Svenska Miljö Emissions Data, Norrköping, Sweden.

Maguire, R.O., and J.T. Sims. 2002. Measuring agronomic and environmental soil phosphorus saturation and predicting phosphorus leaching with Mehlich 3. Soil Sci. Soc. Am. J. 66:2033-2039. doi:10.2136/sssaj2002.2033

McDowell, R., and L. Condron. 2001. Influence of soil constituents on soil phosphorus sorption and desorption. Commun. Soil Sci. Plant Anal. 32:2531-2547. doi:10.1081/CSS-120000389

Meissner, R., P. Leinweber, H. Rupp, M. Shenker, M.I. Litaor, S. Robinson, et al. 2008. Mitigation of diffuse phosphorus pollution during rewetting of fen peat soils: A trans-European case study. Water Air Soil Pollut. 188(1-4):111-126. doi:10.1007/s11270-007-9528-4

Miller, M. 1979. Contribution of nitrogen and phosphorus to subsurface drainage water from intensively cropped mineral and organic soils in Ontario. J. Environ. Qual. 8:42-48. doi:10.2134/jeq1979.00472425000800010011x

Nair, V.D., and D.A. Graetz. 2002. Phosphorus saturation in Spodosols impacted by manure. J. Environ. Qual. 31:1279-1285. doi:10.2134/jeq2002.1279
Nair, V.D., K.M. Portier, D.A. Graetz, and M.L. Walker. 2004. An environmental threshold for degree of phosphorus saturation in sandy soils. J. Environ. Qual. 33:107-113. doi: $10.2134 /$ jeq2004.1070

Olsen, S., and L. Sommers. 1982. Phosphorus. In: A.L. Page et al., editors, Methods of soil analysis. Part 2. 2nd ed. Agron. Monogr. 9. ASA and SSSA, Madison, WI. p. 403-430.

Parvage, M.M., B. Ulén, and H. Kirchmann. 2015. Nutrient leaching from manureamended topsoils (Cambisols and Histosols) in Sweden. Geoderma Reg. 5:209-214. doi:10.1016/j.geodrs.2015.08.003

Peltovuori, T., R. Uusitalo, and T. Kauppila. 2002. Phosphorus reserves and apparent phosphorus saturation in four weakly developed cultivated pedons. Geoderma 110:35-47. doi:10.1016/S0016-7061(02)00180-5

R Core Team. 2014. R: A language and environment for statistical computing. R. Found. Stat. Comput., Vienna, Austria.

Reddy, K.R. 1983. Soluble phosphorus release from organic soils. Agric. Ecosyst. Environ. 9:373-382. doi:10.1016/0167-8809(83)90022-1

Riddle, M.U., and L. Bergström. 2013. Phosphorus leaching from two soils with catch crops exposed to freeze-thaw cycles. Agron. J. 105:803-811. doi:10.2134/ agronj2012.0052

Ryan, J., and P. Gschwend. 1994. Effects of ionic strength and flow rate on colloid release: Relating kinetics to intersurface potential Energy. J. Colloid Interface Sci. 164:21-34. doi:10.1006/jcis.1994.1139

Schmieder, F., L. Bergström, M. Riddle, J.-P. Gustafsson, W. Klysubun, F. Zehetner, et al. 2018. Phosphorus speciation in a long-term manure-amended soil profile: Evidence from wet chemical extraction, 31P-NMR and P K-edge XANES spectroscopy. Geoderma 322:19-27. doi:10.1016/j.geoderma.2018.01.026

Schoumans, O.F. 2013. Description of the phosphorus sorption and desorption processes in lowland peaty clay soils. Soil Sci. 178:291-300.

Schoumans, O.F., and W.J. Chardon. 2015. Phosphate saturation degree and accumulation of phosphate in various soil types in the Netherlands. Geoderma 237-238:325-335. doi:10.1016/j.geoderma.2014.08.015

Schwertmann, U. 1964. Differenzierung der eisenoxide des bodens durch extraktion mit ammoniumoxalat-loesung (In German). Z. Pflanzenernahrung Bodenkd. 105:194-202. doi:10.1002/jpln.3591050303

Sibbesen, E., and A.N. Sharpley. 1997. Setting and justifying upper critical limits for phosphorus in soils In: Phosphorus loss from soil to water. CAB Int. Press, Cambridge, UK.

Simmonds, B., R.W. McDowell, and L.M. Condron. 2017. The effect of soil moisture extremes on the pathways and forms of phosphorus lost in runoff from two contrasting soil types. Soil Res. 55:19-27. doi:10.1071/SR15324

Simmonds, B.M., R.W. McDowell, L.M. Condron, and T. Jowett. 2015. Potential phosphorus losses from organic and podzol soils: Prediction and the influence of soil physico-chemical properties and management. N. Z. J. Agric. Res. 58:170-180. doi:10.1080/00288233.2014.988830

Smet, J.D., G. Hofman, J. Vanderdeelen, M.V. Meirvenne, and L. Baert. 1995. Phosphate enrichment in the sandy loam soils of West-Flanders, Belgium. Fert. Res. 43:209-215. doi:10.1007/BF00747704

Svanbäck, A., B. Ulén, A. Etana, L. Bergström, P.J.A. Kleinman, and L. Mattsson. 2013. Influence of soil phosphorus and manure on phosphorus leaching in Swedish topsoils. Nutr. Cycl. Agroecosyst. 96:133-147. doi:10.1007/s10705-013-9582-9

Tisdall, A., and J. Oades. 1982. Organic matter and water-stable aggregates in soils. J. Soil Sci. 33:141-163. doi:10.1111/j.1365-2389.1982.tb01755.x

Ulén, B. 2004. Size and settling velocities of phosphorus-containing particles in water from agricultural drains. Water Air Soil Pollut. 157:331-343. doi:10.1023/ B:WATE.0000038906.18517.e2

Ulén, B., G. Johansson, A. Gustafson, and H. Johnsson. 2001. Observationfält på åkermark-avrinning och växtnäringförluster för de agrohydrologiska åren 1996/97, 97/98 och 98/99 sämt en långtidsöversikt (In Swedish). Swedish Univ. Agric. Sci., Uppsala.

van der Zee, S.E., and W.H. van Riemsdijk. 1988. Model for long-term phosphate reaction kinetics in soil. J. Environ. Qual. 17:35-41. doi:10.2134/ jeq1988.00472425001700010005x

Wern, L. 2012. Extreme precipitation in Sweden between 1 and 30 days, 19002011 (In Swedish). Meterol. Rep. 143-2012. Swedish Meterol. Hydrol. Inst., Norrköping.

Wuenscher, R., H. Unterfrauner, R. Peticzka, and F. Zehetner. 2016. A comparison of 14 soil phosphorus extraction methods applied to 50 agricultural soils from Central Europe. Plant Soil Environ. 61:86-96. doi:10.17221/932/2014-PSE

Zhang, H., J.L. Schroder, J.K. Fuhrman, N.T. Basta, D.E. Storm, and M.E. Payton. 2005. Path and multiple regression analyses of phosphorus sorption capacity. Soil Sci. Soc. Am. J. 69:96-106. doi:10.2136/sssaj2005.0096dup 